\title{
USING A CONSTRUCTIVIST LEARNING MODEL FOR DEVELOPING SOME CRITICAL READING AND ARGUMENTATIVE WRITING SKILLS AMONG ALAZHAR SECONDARY STAGE STUDENTS
}

\author{
Adly Mohamed Ahmad Ibrahim Alnagar
}

\section{Introduction:}

The ultimate aim of teaching English as foreign language(TEFL) in the secondary stage is to enable learners to use it for authentic communication. Engaging in any form of communication entails mastery of mechanisms by which the person can express emotions and opinions, convey concepts and intentions and respond properly to any situation. Recently, the growing development of information and communication technology has made critical reading and argumentative writing more essential. Logging on to the varied digital resources and keeping into contact with others via e-mail and other social communication sites have increasingly become indispensable activity of everyday life. Hence, more emphasis should be given to teaching those skills to enable learners to become more competent and critical when interacting with any media.

Language learning does not only involve internalizing sets of rules, structures and forms; each learner brings her/his own experience and world knowledge to put up with the target language or task at hand. Apparently, constructivism supports autonomy that relates to learners' behavior, attitudes, motivation and selfconcept. As a result, constructivism approaches encourage and promote selfdirected learning as a necessary condition for learner autonomy.

A well-balanced course should consist of four equal strands. These strands are called meaning-focused input (reading and listening), meaning- focused output (speaking and writing), language-focused learning (vocabulary, grammar, sound and spelling), and fluency development. Through these strands, learners achieve the language goals; namely, fluency of the sound, spelling, vocabulary, grammar so that learners can read and write effectively (Newton, 2009).

Reading and writing are language skills through which the individual can communicate with the surrounding world. They are lifelong skills that foster each other; and represent mechanisms of selfexpression and construction of knowledge. (Wallace, 2003). Having a good command of these skills helps to achieve a higher level of language proficiency and enable the learner to effectively interact with today's information variables . Reading is one of the four language skills that require special attention, as it is a receptive language process. It is the process of recognition, interpretation, and perception of written or printed materials. Reading proficiency plays an important role in understanding a written statement accurately and effectively. It serves as an important tool in every field of professional service. In many situations, reading is considered to be an indispensable channel of communication in an ever widening world. In fact, people are living in "reading" world where it is difficult to manage without (Al-Qadi, 2007).In the same respect,(Brown, 1994) reported that reading has been considered as an process rather than a passive one where the reader interacts with the text 
before, during and after the reading task.( Padesky, 1995) also stated that "reading is the process of readers interacting meaning from text by implementing the prior knowledge and information found in the text and stated that reading is seen as active process of comprehension where students need to be taught strategies to read more efficiently e.g. Guess from the context, identify the author's purpose and attitudes define expectations and make inferences about the text, skim ahead to fill in the context".

Writing, on the other hand, is one of the main four skills in language learning. It is a lifelong skill that everyone needs to communicate effectively. Further, it is a tool for creation of ideas and consolidation of the linguistic system by using it for communicative objectives in interactive way, (Boughey, 1997). (Leeds, 1996) views writing as a" protected process through which ideas are explored, elaborated, and finally shaped for the reader". In other words, it is one of the most authentic and interactive ways of transferring thoughts and ideas to others. It is negotiable and explanatory act, requiring great judgments. Learning to write varied forms of writing efficiently is a long process that requires much practice and sometimes explicit and formal instruction. The act of writing creates an environment for the development of cognitive and organizational strategies whereby students link new ideas with familiar ones, synthesize knowledge, explore relations and implications, outline information, and strengthen conceptual frameworks. Thus, it involves selfmonitoring, planning, concept-building, and the review of information processes, which promote the building of knowledge domain. (Helwa, 2014)

Argumentative writing is one of the writing modes that promote reasoning and critical thinking skills which are often figured in the democratic society where different point of views are criticized, analyzed and supported. To give this point of view, student considers his opinion on a controversial issue and supports his opinion with arguments for the purpose of getting the audience to change their mind on the controversial issue to reflect his point of view. Ultimately, the writer is successful when the audience accepts his or her beliefs on the ground of his or her discourse, (Moore 2009).( Ismail2001) emphasized that "through writing, students share ideas, arouse feelings, and convince other people, they are able to discover and articulate ideas in ways that only writing makes possible" Argumentative writing is one of the writing style which needs to a critical reader to analyze, criticize and create evidences and details that support their controversial viewpoints.

Briefly, reading critically and writing efficiently are inseparable processes that foster each other. The act of writing doesn't merely begins with having a good command of basic technical skills, but it simply begins with having data and ideas to reflect an intended purpose and to write something that sounds logical, purposeful, and meaningful. Thus, based on the above mentioned, it can be concluded that it is necessary for secondary stage students to read and write critically. For achieving prerequisite, learner-centered approaches in teaching should be utilized. One of the prominent learner centered approaches is the Constructivism learning strategy that draws on students' existing knowledge, beliefs, and skills. With a constructivist approach, students synthesize new understanding from prior learning and new information. The constructivist teacher sets up problems and monitors student exploration, guides student inquiry, and promotes new patterns of thinking. Working mostly with raw data, primary sources, and interactive material, constructivist teaching asks students to 
work with their own data and learn to direct their own explorations. Ultimately, students begin to think of learning as accumulated, evolving knowledge. Constructivist approaches work well with learners of all ages, including adults.

The constructivist five E's model for Bybee, a constructivist approach in teaching language, has useful implications to teaching and can lead to better results in language teaching. The 5Es model is based upon effective and proven educational theories and has an expanding base of research to support its use in the classroom (Balci et al., 2006; Bybee et al., 2006) to improve education and to help teachers and students meet the high expectations of the high stakes testing environment.

The 5E's model of instruction may help teachers overcome some of challenges, such as a lack of student interest in learning or the inability of students to relate to the content being taught in the language classrooms. The effective and consistent use of the 5E's model may help teachers address some of these and other deficits in education system. Through the effective use of the 5Es model, teachers can create classroom environments where students take an active role in their education, which is a necessary component for successful modern education. Through the use of the 5E's model, teachers can also encourage the development of problem solving skills and meaningful conceptual understandings, which is another necessary component of successful modern education (Lee \& Buxton, 2008; Magharious \& McCracken, 2009). "Effective teaching practices in high schools encourage students to solve problems that are of interest to them and to construct objects and perform experiments, reflect on real-life experiences, and access information through technology". The Consistent and effective use of the 5E learning cycle model may be the first step to eliminating the achievement gap in language education. The constructivist learning model by (Trowbridge and Bybee 1990) five E's model consists of five phases Each of the 5 E's describes a phase of learning, and each phase begins with the letter "E": Engage, Explore, Explain, Elaborate, and Evaluate. The 5 E's allows students and teachers to experience common activities, to use and build on prior knowledge and experience, to construct meaning, and to continually assess their understanding of a concept, they are the as follows (El-Nagdy et al, 2005)

\section{1- Engagement:}

The engage component in the 5E's model is intended to capture students' attention, get students thinking about the subject matter, raise questions in students' minds, stimulate thinking, and access prior knowledge the engage component includes both accessing prior knowledge and generating enthusiasm for the subject matter. The students establish an interest in and develop an approach to the instructional task. The teacher provides the experiences necessary to engage the learner. Identify the instructional task.

\section{2- Exploration}

In the exploration stage students have the opportunity to get directly involved with the materials. Involving themselves in these activities develop grounding of experience with the materials. As they work together in teams, students build base of common experience which assists them in the process of sharing and communicating. The teacher acts as a facilitator, providing materials and guiding the students' focus, Facilitates and monitors interaction between students and instructional situations, materials, and course ware. 


\section{1- Explanation:}

This is the point at which the learner begins to put the abstract experience through which $\mathrm{s} / \mathrm{he}$ has gone into a communicable form. Language provides motivation for sequencing events into logical format. Common language enhances the communication between the facilitator (teacher) and the learner. The facilitator can determine levels of understanding and possible misconceptions. Created work such as writing, drawing, video, or tape recordings are communications that provide recorded evidence of the learner's development progress and growth. Students describe their understanding, use their skills, and express their attitudes. Facilitators introduce formal terms, definitions, and explanations for concepts, processes, skills, or behaviors and suggesting further learning experiences.

\section{2- Elaboration:}

In this stage, the students expand on the concepts they have learned, make connections to other related concepts, and apply their understandings to the world around them. These connections often lead a new understanding. Students develop deeper and broader understanding of major concepts, obtain more information about areas of interest, and refine their skills. Facilitators provide an occasion for students to cooperate on activities, discuss their current understanding, and demonstrate their skills.

\section{3- Evaluation}

The fifth "E", is an on-diagnostic process that allows the facilitator to determine if the learners have attained understanding of concepts and knowledge. Evaluation and assessment can occur at all points along the continuum of the instructional process. Some of the tools that assist in this diagnostic process are rubrics, teacher observation structured by checklists, tests, project and problem-based learning products, and other tests. Students assess their understanding and abilities and teachers evaluate students' understanding of key concepts and skill development.

\section{Related Studies}

This section surveys three main types of related studies. The first type is concerned with the critical reading skills, the second type is concerned with the argumentative writing skills and the third type is about the constructivism and the constructivist learning model(5 E's learning model)

\section{A. Studies related to the critical reading skills:}

This section explores the studies that dealt with the critical reading skills in relation to the factors affecting it.

Lasheen (2012) investigated the effectiveness of a courseware in the English language based on narrative technique to develop some critical reading Skills for secondary school students . The results indicated that there is a statistically significance difference between the mean scores of the experimental group and that of the control group in the critical reading skills in favor of the experimental group.

Ebedy (2013).conducted a study aimed at improving prep school reading and writing skills and their attitudes towards English language. To achieve this goal a constructivism-based program was applied, the program integrated and adopted taxonomy of reading and writing strategies that consists of cognitive, metacognitive, memory and socioaffective strategies. The results indicated that there is a statistically significance difference between the mean scores of the experimental group and that of the control group in the reading and writing skills in favor of the experimental group.

Mansour (2013) used a suggested program for developing EFL reading and writing skills among secondary school students in light of the constructivist learning approach. The Results showed that there is significant difference 
between the mean scores of the experimental group students in the pre and post measurement on reading and writing skills test as a whole in favor of the post measurement. It is concluded that the proposed program was effective in developing the necessary reading and writing skills among students.

Al-Neguiy(2013) used project-based learning strategy to develop EFL secondary stage students' writing and critical reading skills. The study aimed at developing EFL secondary stage students' critical reading and writing skills through using project- based learning. The study adopted the quasi experimental

design. The experimental group was engaged in conducting a project as well as studying the syllabus prescribed in the text book "Hello! English for secondary for secondary school, first year. Results have indicated that the performance of the experimental group in both critical reading and writing skills have improved significantly. It is concluded that engaging students in authentic and constructivist learning environment, helps students use English for real purpose, explore more with language, apply concepts and construct knowledge.

Zaky(2014) investigated the effect of using electronic mind mapping on developing first year secondary stage students' EFL critical reading skills. A randomly selected group of the first year secondary students $(\mathrm{n}=40)$ received training throughout the proposed program based on using electronic mind mapping for developing critical reading skills. A pre-posttest was designed and applied to the group before and after the implementation of the program. Results of the study indicated that electronic mind mapping has effective influence on promoting EFL critical reading skills. The study recommended that critical reading skills need to be developed in early stages.
The previously explored studies reviewed the critical reading in its relation with various factors that can affect its development. It can be seen that many studies affirmed that mind map, questioning strategies, project based strategies and of cognitive, metacognitive, memory, socio-affective strategies to be effective in developing the critical reading skills.

\section{B. Studies related to the argumentative writing skills:}

This section explores the studies that dealt with the argumentative writing skills in relation to the factors affecting it.

Ali(2011). The study aimed at investigating the effect of a suggested program based on multiple intelligences on developing some argumentative writing skills of the fourth-year primary education prospective teachers of English. One-pre- post experimental group design was used. Results of the study revealed that there are statistically significant differences between the pre and the post teston the knowledge part and the performance part of the argumentative writing test. Recommendations included a call for incorporating MI- based instruction in teaching argumentative writing, so students' dominated intelligences can be activated and utilized in learning process, a call for devoting more time in the writing class to allow students to follow different composing styles that are appropriate to their different kinds of intelligences. It is concluded that MI-based learning gave students more chance to argue debatable issues that are closely related to their reallife situations and provided students a relaxing positive teaching/learning environment that helped them to develop argumentative writing skills.

El-Deen(2014)studied the effectiveness of an FEL program based on Freirean pedagogy in developing secondary school students' argumentative writing skills and 
reflective thinking, the study adopted the quasi-experimental, pre-post, and experimental and control group design. The study results revealed that there were statistically significant differences at 0.01 level between the mean scores of the control and the experimental groups on the posttest in favor of the experimental group in overall argumentative writing skills as well as in each argumentative writing skill. There were also statistically significant differences at 0.01 level between the mean scores of the experimental group in the preadministration and post-administration of reflective thinking in favor of the post administration.

Helwa (2014)studied the effectiveness of a program based on the combination of relevance and confidence motivational strategies in developing EFL argumentative writing skills and overcoming writing apprehension among students teachers at faculty of education The results of the study revealed that the participants' EFL argumentative writing skills developed after the implementation of the combination of relevance and confidence motivational strategies based program. In addition, their writing apprehension was decreased, they became much more motivated and encourage to express their own opinions and points of view in writing without fearing from anything. The significance differences found in favor of the post assessment of the EFL argumentative writing skills and the pre assessment of the writing apprehension can be ascribed to the implementation of the combination of relevance and confidence motivational strategies based program. Thus, the program proved to be effective in developing EFL argumentative writing skills and overcoming writing apprehension among the participants of the study

\section{C- Studies related to constructivism theory :}

This section explores the studies that dealt with constructivism and the constructivist learning models in relation to the factors affecting it.

Manson(2001)provided evidence that reasoning and arguing collaboratively on different beliefs and ideas, as well as individual writing to express and reflect and communicate one's own conceptions, stimulated and sustained meta-conceptual awareness in a class of fourth-graders in science. Finding revealed that reasoning and arguing collaboratively on different beliefs, as well as individual writing to express, clarify and reason on, and communicate own conceptions and explanations, were valued as productive tools in the knowledge revision process.

$\operatorname{Koc}(\mathbf{2 0 0 2})$ examined the effects of constructivist learning environment on learners' affective and cognitive learning outcomes at a vocational education faculty in development of preschool instructors. An experimental design was used and findings showed significant differences in the achievement on higher level learning and their retention and problem-solving skills.

El-fiky(2006) carried out a research on the effectiveness of a cooperative learning strategy in enhancing composition writing skills and the attitudes of Al- Azhar secondary students, the results showed that the cooperative learning strategy helped the experimental group students to construct correct sentences through the students' cooperation the thing that highlight the importance of the social cooperation in developing writing skills.

Mitry(2009) conducted a study aimed at developing some technical writing genres in English for applied arts students in the light of constructivism learning the results approved the effectiveness of the program in enhancing the writing skills for the experimental group. 
Mahmoud (2007) examined of applying constructivist-learning model in AlFayouum preparatory schools on the second cycle of basic education learners' acquisition of some grammatical concepts and their attitudes towards using the model. One class of each school acted as the experimental group and the other as the control group. The searcher compared the results of using five E's constructivist learning model with traditional method. The statistical analysis proved that there was statistically significant difference at 0.01 level between the average grades of students who studied the grammatical concepts according to five E's constructivist learning-model (experimental group) and those who studied the same unit using according to the traditional method in favor of the post administration. The results showed that five E's learning model was effective in acquiring the target students some grammatical concepts.

Hamdy(2008)examined the effectiveness of using a constructivist learning model in developing achievement and scientific thinking in a school of Giza, Al- Haram preparatory school for girls. She compared the results of using the constructivist learning model with the traditional method. The statistical analysis showed that there were statically significant difference at 0.01 level between the average grades of students who studied the unit using the constructivist- learning model (experimental group) and those who studied the same unit according to traditional method (control group)in the total grade of the achievement test, in levels of cognitive, memorizing, understanding and application, and in the total grade for the scientific thinking test in the post-administration.

$\operatorname{Rizk}(\mathbf{2 0 0 8})$ investigated the effectiveness of a constructivism-based program in developing the listening skills of EFL primary student teachers in faculty of education, Mansoura University. The researcher identified the listening skills necessary for the targeted students then assessed their level on these skills. The pre-post experimental design was adopted using one group to assess improvement in student teachers' listening skills. The results showed that the proposed treatment for listening skills based on the constructivism theory of learning boosted learners' autonomy. Moreover, there was a significant improvement in student teachers' listening skills component dimensions of word and sentence recognition, comprehension and critical thinking.

Ayed (2011) studied the effect of using a suggested jigsaw based program on developing critical thinking, reading and reading motivation of first year English majors, to investigate the effectiveness of the program 60 students were divided into experimental and control groups (30 each group) the experimental group was taught in cooperative jigsaw II as instruction method, while the control group was taught through the traditional way. The results indicated that the cooperative learning jigsaw II is more effective than the traditional method.

El-Deen(2011).The study aimed at developing the necessary metacognitive reading skills for Egyptian EFL first year secondary school students, through the use of a proposed program based on social constructivist learning model (scaffolding). The study adopted the quasi-experimental pre-posttest control/experimental group design. The study results revealed evidence that there were statistically significant differences at 0.01 level between the mean scores of the control and the experimental groups on the post test in favor of the experimental group in overall metacognitive reading skills as well as in each at 
0.01 level between the mean scores of the experimental group in the preadministration and post-administration of the metacognitive reading skills awareness inventory in favor of the post administration.

Eltorky (2014) studied the effectiveness of an FEL program based on constructivism theory in developing business administration students' writing skills, the study aimed at overcoming the shortcomings in teaching business technical writing skills for business administration students by using four constructivist strategies. These strategies are: scaffolding, mind mapping, problembased learning, and inquiry-based learning. Besides, it emphasized the importance of providing EFL students with activities and opportunities to develop their awareness of learning, as it helped students understand how to plan, monitor and evaluate their learning. Results showed that there is significant difference between the mean scores of the experimental group students in the pre and post measurement on the business technical writing skills test as a whole in favor of the post measurement. It is concluded that the proposed program was effective in developing the necessary business technical writing skills among students.

The previous studies confirmed that using a constructivist learning model can contribute to develop the critical reading and argumentative writing skills. The present study made use of the results of these studies to establish the premise that critical reading and argumentative writing skills can be improved through a applied model based on constructivism theory. Also, there are studies which tried to develop the reading or writing skills in general, but the present study tried to develop some critical reading and argumentative writing skills. So, using the constructivist learning model may be effective in helping students develop some of these critical reading and argumentative writing skills.

\section{Need for the study:}

Being a teacher of English at Al-Azhar secondary stage for more than twelve years at different institutes, the researcher observed a weakness in the critical reading and argumentative writing skills of most secondary stage students, the ability to interpret and criticize when reading a text. They cannot grasp the underlying meaning that helps them construct viewpoints and reasonable judgments. They only read to answer the underline questions in their exams or they answer the questions assimilating the question words with the text

words. In addition to that, they exhibit poor writing skills. They lack the ability to produce an argumentative paragraph supporting a point of view using the evidences and proofs to strengthen their opinions. They are unable to address varied readers but they are specially needed to adapt an idea and defend it and persuade the reader by evidences and proofs. Hence, the present study attempts to investigate the effectiveness of using the 5E's learning model for enhancing the critical reading and argumentative writing skills for the second year secondary stage students.

\section{The statement of the problem:}

There is a weakness in Al-Azhar secondary stage students' critical reading and argumentative writing skills. The literature suggests that employing the constructivist learning model(5E's learning ) may be useful in tackling this problem. Therefore, this study attempts to answer the following major question: What is the effectiveness of using some a constructivist learning model in developing the critical reading and argumentative writing skills of AlAzhar second year secondary stage students? 
To answer this question, the following sub-questions will be attempted:

1. What is the actual status of critical reading and argumentative writing skills of students at the second secondary stage?

2- What are the EFL critical reading skills that students of second secondary stage should develop to be critical readers?

3- what are the EFL writing skills those students of second secondary stage should develop?

4. What are the features of the constructivist learning model (five E,s model) designed for developing some critical reading and argumentative writing skills of second secondary school students at this level?

5. What is the effect of the model in developing some critical reading and argumentative writing skills at this level?

Hypotheses of the study:

This study attempted to verify the following hypotheses:

1- There is a statistically significant difference between the mean score of the experimental group and that of the control group on the post critical reading test favoring the experimental group.

2- There is a statistically significant difference between the mean score of the experimental group and that of the control group on the post argumentative writing test favoring the experimental group.

3 -There is a statistically significant difference between the mean scores of the experimental group students on the pre and the post critical reading test favoring the post test..

4-There is a statistically significant difference between the mean scores of the experimental group students on the pre and the post argumentative writing favoring the post test.
Limitations of the study: The present study proceeded within the following limits:

-Two classes from the second year secondary stage, Beni Harb institute for girls.

-Five reading texts from the second year book. (Hello! English, year two)

-Developing some critical reading skills classified in accordance with the cognitive domain of the revised Bloom's taxonomy (the higher order process: analyzing-evaluating-creating).

1- Identify the main ideas

2- Discover causes and effects

3- Make comparison and contrast

4- Identify the author's purpose (to entertain, inform or persuade ....etc.) 5- Understand the relation among parts of a text

6- Distinguish facts from opinions.

7- Distinguish relevant information from irrelevantinformation

8- 8-Form personal justified opinion

9-Create a (topic, plan, solution......etc) 10-Predict consequences

11-Make connection between the reading text and his prior knowledge 12- Make generalization

-Three writing topics relating to the syllabus of the second secondary stage.

-Developing writing skills that are related to content, organization, grammar usage, word choice and mechanism of writing.

-Teaching specific forms of writing that suit Argumentative skills, supporting ideas and making evidences. The study will be limited to the following six argumentative writing skills:

1-analyze opinions

2-Evaluate opinions.

3- State the opposite point of view

4- Design an outline of an argumentative composition.

5- 5-Write a well-organized introduction 
6- Write a well-organized body

7- Write a well-organized conclusion.

8- Write a clear, convincing thesis statement

9- Write a positive thesis statement

10 -Write a negative thesis statement

11-support argument.

12-give reasons for argument.

Methodology:

A) Sample of the study:

Participants in this study were selected from the second year secondary institute(Beni Harb secondary institute for girls) the participants age ranged from sixteen to seventeen years old

B) Setting of the study:

The study is carried out at Beni-Harb Institute in Tahta, Sohag where
English is taught as a foreign

language.

C) Design of the study:

The study adopted quasi-experimental design. Two classes were assigned to an experimental group and to a control group. The two groups were pretested to determine the actual performance both in critical reading and argumentative writing skills. Then, the experimental group was taught through the syllabus prescribed in the text book as well as conducting the proposed model (the five E's learning model). On the other hand, the control group was taught only through the traditional way of teaching. The two groups were post-tested in critical reading and writing skills to measure any possible improvement. As shown:

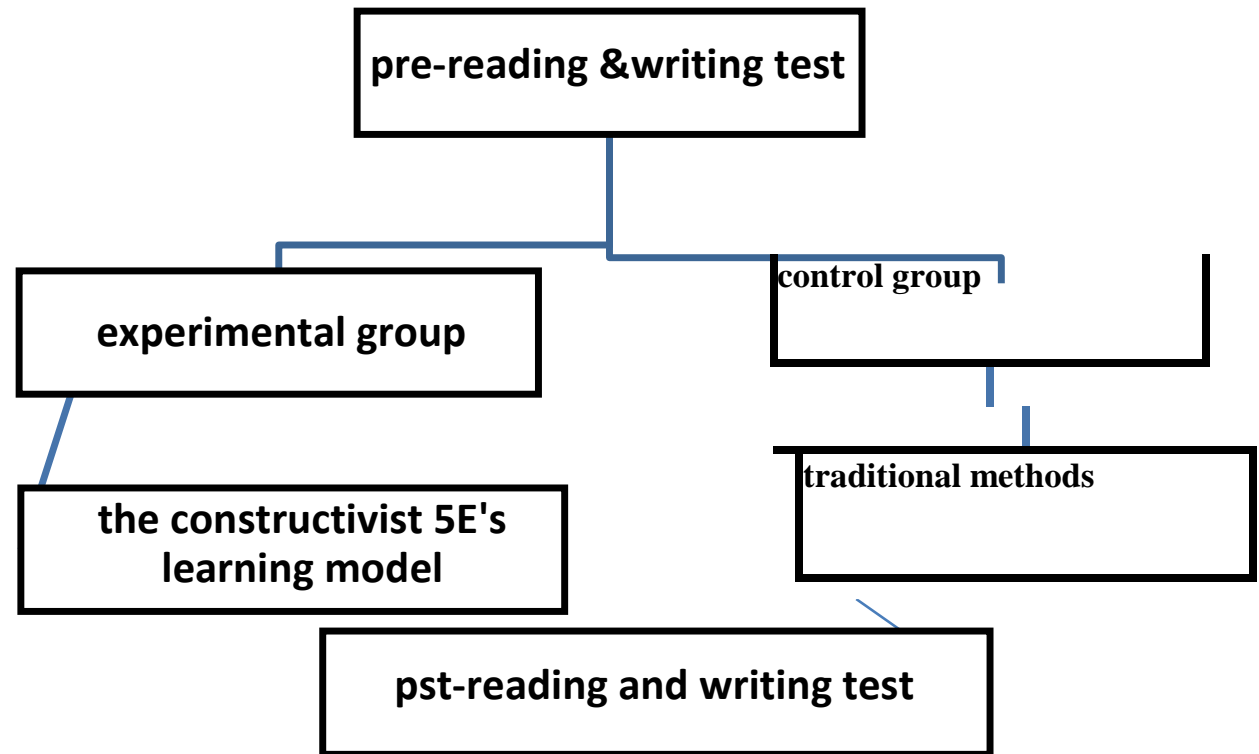

Source: original

D) Instrument of the study:

The following instruments will be used: -A critical reading skills checklist. (Used to specify a list of critical reading skills needed to be developed by second year secondary stage)

Figure:1 Quasi- Experimental Design.

-A writing skills checklist. (Used to specify a list of writing skills needed to be developed by second year secondary stage)

-A critical reading test (used as pre-posttest) 
-An argumentative writing test. (Used as pre-post- test)

-Scoring rubric for the performance of argumentative writing.

E) Procedures of the study:

In order to answer the questions of the study, the study proceeded according to the following steps:

(A) To answer the first question of "What is the actual status of critical reading and argumentative writing skills of students at the secondary stage?" the following steps were carried out:

1- Developing a critical reading and an argumentative writing skills test on the skills identified from the questionnaire.

2- Preparing and validating an Analytical scoring rubric to assess the performance of the target group performance in writing before and after the experiment.

3- Presenting the test to jurors for validation.

4- Modifying the test according to jurors' opinions to its finalform.

5- Piloting the tests to measure their reliability.

6- Choosing the sample of the study (two classes from the second year secondary school Beni Harb institute for girls).

7- Admenistrating the critical reading and argumentative writing skills tests before implementing the model to the experimental group (the pretest) (B)-To answer the first question of "what are the critical reading skills necessary for the second year secondary stage students "the following steps were carried out:

8- Reviewing related literature and previous studies to identify critical reading skills necessary for second year secondary stage students.

9- Preparing a list of the critical reading skills.
Developing a critical reading skills questionnaire to be presented to specialists, e.g. Faculty professors, supervisors and teachers to determinethe critical reading skills necessary for those students.

10-Determining the critical reading skills according to jurors' opinions.

(C) To answer the second question of "what are the argumentative writing skills necessary for the second year secondary stage students "the following steps were carried out:

11-Reviewing related literature and previous studies to identify the argumentative writing skills necessary for second year secondary stage students.

12-Preparing a list of the argumentative writing skills.

14-Developing an argumentative writing skills questionnaire to be presentedto specialists, e.g. Faculty professors, supervisors and teachers to determine the argumentative writing skills necessary for those students.

15-Determining the argumentative writing skills according to jurors' opinions.

(D) To answer the third question of "What are the features of the constructivist learning model (five E's model) designed for developing some critical reading and argumentative writing skills of secondary school students at this level?" the following steps were carried out:

16-Reviewing related literature and previous studies to identify the features of the constructivist learning model (five E's model)

(E)To answer the fourth question of "What is the effect of the model in developing some critical reading and argumentative writing skills at this 


\begin{tabular}{|c|c|c|c|c|c|c|c|}
\hline \multicolumn{4}{|c|}{$\begin{array}{l}\text { level?" the following steps were } \\
\text { carried out: } \\
\text { 17-Implementing the proposed } \\
\text { constructivist learning model to the } \\
\text { experimental group. } \\
\text { 18- Admiistrating the critical reading } \\
\text { and argumentative writing skills tests } \\
\text { to the experimental group (the post- } \\
\text { test) } \\
\text { 19- Analyzing the data statistically using } \\
\text { the appropriate statistical methods. } \\
\text { 20-Discussing results and providing } \\
\text { conclusions andrecommendations. } \\
\text { Results and discussions } \\
\text { First hypothesis: There is a statistically } \\
\text { significant difference between the mean } \\
\text { scores of the experimental group and } \\
\text { those of control pupils on the post critical } \\
\text { Table (1): T-test results for the exper } \\
\text { reading test. }\end{array}$} & \multicolumn{4}{|c|}{$\begin{array}{l}\text { reading test (analyzing-evaluating, anc } \\
\text { creating) favoring experimental group. } \\
\text { To test this hypothesis the researche } \\
\text { used: } \\
\text { 1-T-test for independent samples. } \\
\text { 2-Partial Eta square }\left(\square^{2}\right) \text { to measure the } \\
\text { effect size for the model. } \\
\text { 1- Results of } \mathbf{T} \text { - test for independen } \\
\text { samples. } \\
\text { Hypothesis (1): to test the first hypothesi } \\
\text { which addressed the difference betweer } \\
\text { the experimental and the control group or } \\
\text { the post-administration of the critica } \\
\text { reading test, a t-test for independen } \\
\text { samples was employed. Table(1) show: } \\
\text { the results. } \\
\text { ntal and control groups on the critica }\end{array}$} \\
\hline domains & group & $\mathbf{n}$ & Mean & S D & $\mathbf{T}$ & $\begin{array}{l}\text { Level } \\
\text { of sig }\end{array}$ & Sig at \\
\hline analyzing & control & 25 & 6.16 & 1.2477 & 16.9 & \multirow{8}{*}{0.000} & \multirow{8}{*}{0.05} \\
\hline & Exp. & & 13 & 1.5811 & & & \\
\hline \multirow[t]{2}{*}{ evaluating } & control & 25 & 3.84 & 0.5538 & \multirow[t]{2}{*}{38.7} & & \\
\hline & Exp. & & 10.96 & 0.7349 & & & \\
\hline \multirow[t]{2}{*}{ creating } & control & 25 & 16.08 & 2.6287 & \multirow[t]{2}{*}{13.3} & & \\
\hline & Exp. & & 24.92 & 2.0191 & & & \\
\hline \multirow[t]{2}{*}{ total } & control & 25 & 26.08 & 3.0128 & \multirow[t]{2}{*}{30.9} & & \\
\hline & Exp. & & 48.88 & 2.1276 & & & \\
\hline
\end{tabular}

Table (1) shows that the mean scores of the experimental group students in the post administration of the EFL critical reading test and in the total were higher than those of the control group. The table illustrates also that the estimated t-value is significant at .05 level. This indicates that there are statistically significant differences between the experimental and control groups in the three stages of critical reading test and in the total score on the post- administration of the test favoring the experimental group

Hypothesis (2): to test the second hypothesis which addressed the difference between the scores of the experimental group on the pre-post administration of the EFL critical reading, a t-test for dependent samples was employed. Table (2) shows the results. 
Table(2): Results of t-test of the experimental group on the pre-post- administration of the EFL critical reading skills.

\begin{tabular}{|c|c|c|c|c|c|c|c|}
\hline $\begin{array}{l}\text { Parts of } \\
\text { the test }\end{array}$ & measurement & $\mathbf{n}$ & Mean & S D & $\mathbf{T}$ & $\begin{array}{l}\text { Level } \\
\text { of sig }\end{array}$ & $\begin{array}{c}\text { Sig } \\
\text { at }\end{array}$ \\
\hline \multirow[t]{2}{*}{ analyzing } & Pre & \multirow[t]{2}{*}{25} & 6.88 & 1.36 & \multirow[t]{2}{*}{15} & \multirow{8}{*}{0.000} & \multirow{8}{*}{0.05} \\
\hline & post & & 13.04 & 1.47 & & & \\
\hline \multirow[t]{2}{*}{ evaluating } & Pre & 25 & 4.4 & 1 & \multirow[t]{2}{*}{14.9} & & \\
\hline & post & & 9.80 & 1.22 & & & \\
\hline \multirow[t]{2}{*}{ creating } & Pre & 25 & 14.76 & 1.85 & \multirow[t]{2}{*}{25.1} & & \\
\hline & post & & 25.48 & 1.56 & & & \\
\hline \multirow[t]{2}{*}{ total } & Pre & 25 & 26.04 & 2.79 & \multirow[t]{2}{*}{29.5} & & \\
\hline & post & & 48.32 & 2.30 & & & \\
\hline
\end{tabular}

Results in the above table illustrate that the estimated t-value is significant at 0.05 level. This indicates that there are statistically significant differences between the mean scores of the pre-postadministration of the EFL critical reading test in its three parts and in the total score. These significant differences are in favor of the post-test.

Table (3): T-test results for the experimental and control groups on the post argumentative writing test.

\begin{tabular}{|c|c|c|c|c|c|c|c|}
\hline domains & group & n & $\begin{array}{c}\text { Mea } \\
\mathbf{n}\end{array}$ & S D & $\mathbf{T}$ & $\begin{array}{l}\text { Level } \\
\text { of sig }\end{array}$ & Sig at \\
\hline \multirow{2}{*}{$\begin{array}{l}\text { Making the } \\
\text { right argument }\end{array}$} & control & \multirow[t]{2}{*}{25} & 5.2 & 0.9129 & \multirow[t]{2}{*}{13.1} & \multirow{8}{*}{0.000} & \multirow{8}{*}{0.05} \\
\hline & Exp. & & 9.96 & 1.5674 & & & \\
\hline \multirow[t]{2}{*}{ organization } & control & \multirow[t]{2}{*}{25} & 5.04 & 1.1719 & \multirow[t]{2}{*}{18.5} & & \\
\hline & Exp. & & 11.28 & 1.2083 & & & \\
\hline \multirow{2}{*}{$\begin{array}{c}\text { Thesis } \\
\text { statement }\end{array}$} & control & \multirow[t]{2}{*}{25} & 6.24 & 1.0116 & \multirow[t]{2}{*}{21.1} & & \\
\hline & Exp. & & 12 & 0.9129 & & & \\
\hline \multirow[t]{2}{*}{ Total } & control & \multirow[t]{2}{*}{25} & 16.48 & 1.8511 & \multirow[t]{2}{*}{30.7} & & \\
\hline & Exp. & & 33.24 & 2.0058 & & & \\
\hline
\end{tabular}

Table (3) shows that the mean scores of the experimental group students in the post administration of the EFL argumentative writing test and in the total were higher than those of the control group. The table illustrates also that the estimated t-value is significant at 0.05 level. This indicates that there are 
statistically significant differences between the experimental and control groups in the three stages of argumentative writing test and in the total score on the post-administration of the test favoring the experimental group.
Hypothesis (4): to test the second hypothesis which addressed the difference between the scores of the experimental group on the pre-post administration of the EFL argumentative writing, a t-test for independent samples was employed. Table (4) shows the results.

Table(4): Results of t-test of the experimental group on the pre-post- administration of the EFL argumentative writing skills.

\begin{tabular}{|c|c|c|c|c|c|c|c|}
\hline Parts of the test & $\begin{array}{l}\text { measur } \\
\text { ement }\end{array}$ & $\mathbf{n}$ & Mean & S D & $\mathbf{T}$ & $\begin{array}{l}\text { Level } \\
\text { of sig }\end{array}$ & Sig at \\
\hline \multirow[t]{2}{*}{ Making the right argument } & Pre & \multirow[t]{2}{*}{25} & 4.8 & 1.472 & \multirow[t]{2}{*}{7.4} & \multirow{8}{*}{0.000} & \multirow{8}{*}{0.05} \\
\hline & post & & 8.20 & 1.4 & & & \\
\hline \multirow[t]{2}{*}{ organization } & Pre & \multirow[t]{2}{*}{25} & 5.28 & 1.39 & \multirow[t]{2}{*}{8.5} & & \\
\hline & post & & 9.56 & 1.2083 & & & \\
\hline \multirow[t]{2}{*}{ Thesis statement } & Pre & \multirow[t]{2}{*}{25} & 5.84 & 1.546 & \multirow[t]{2}{*}{15.2} & & \\
\hline & post & & 11 & 1.19 & & & \\
\hline \multirow[t]{2}{*}{ Total } & Pre & \multirow[t]{2}{*}{25} & 15.92 & 2.0599 & \multirow[t]{2}{*}{24.9} & & \\
\hline & post & & 28.76 & 2.06 & & & \\
\hline
\end{tabular}

Results in the above table illustrate that the estimated t-value is significant at 0.05 level. This indicates that there are statistically significant differences between the mean scores of the pre-postadministration of the EFL argumentative writing test in its three parts and in the total score. These significant These significant differences are in favor of the post-test

\section{Conclusions:}

Based on the results obtained, it is concluded that engaging students in constructivist learning environment is of significant effect on developing EFL second year secondary school students' critical reading and argumentative writing skills. The constructivist 5E's learning model implements features of constructivism and integrates theory and practice. It provides students with real life challenges and living experiences that enable learners to use English for real purposes and express their opinions, believes and feeling, develop learning skills, and apply concepts. As follow:

1- The present study provided evidence for the effectiveness of using the constructivist learning model in developing the students' critical reading and argumentative writing skills. This result is in line of the findings reported by

Mahmoud (2007), Hamdy(2008), Mitry (2009), El-Deen(2011), and Eltorky (2014)

The present study highlighted the possibility of using a constructivist learning model (5E's learning model) for developing the critical reading skills among Al-

Azhar second year secondary students.

1- The constructivist learning model (5E's learning model) integrates so many aspects that enhance active learning and positive attitude towards the critical reading and argumentative writing skills. 


\section{Recommendation: \\ Based on the findings of the study, the following recommendation could be offered:}

- EFL curriculum designers and developers should plan to incorporate 5E's learning model in TEFL curriculum as a constructivist paradigm. This helps provide learners with authentic learning environment through which learning outcomes can achieved; knowledge can be constructed, life skills can be acquired.

- Future education policy should adopt pioneer pedagogical methods based on constructivism theory.

- Logistic arrangements should be provided to the educational situation to create the appropriate environment for creativity and innovation.

- Acquiring both pre-service and in service teachers with the rationale method and the value of using the constructivist learning model in TEFL context through systematic training courses.

- More emphasis should be given to the learner's individual creativity and creation by involving thinking process such as applying knowledge, information reasoning and discussing ideas.

- More consideration should be taken to enhance students' awareness of the critical reading skills through explicit instruction from the early classes.

- More consideration should be taken to enhance students' awareness of the argumentative writing skills through explicit instruction from the early classes.

- Students should be trained on the critical reading and the argumentative writing skills through reading and writing about varied topics using constructivist learning techniques.

Reading texts in EFL reading classes should be periodically in away stimulate the students' higher-order critical reading skills and develop the sensitivity with the world around.

- Writing in EFL writing classes should be an opportunity for the students to write about his own opinions in a communicative environment maintain the chance of discussion and exploration.

- Balanced assessment approach(authentic, formative, and summative)should be adopted in the Egyptian educational system. This helps enhance the overall development of the learning outcomes(knowledge, skills, and attitudes).

- The scope of the English course syllabus should be modified to be more flexible to help teachers to manage the curricular units in innovate and creative ways.

- The future educational policies should due care to highlight the st 21 century skills (e.g. Team workself-direction-critical thinkingcreativity- persuading and argumentative writing)

References:

1) Ali, A.(2011). The effect of a suggested multiple intelligences based program on developing some argumentative writing skills of primary education prospective teachers of English at Sohag faculty of education. Unpublished M A thesis, Faculty of Education, Sohag University 
2) Al-Neguly, W.(2013): Using project- based learning to develop EFL secondary stage students' writing and critical reading skills. Unpublished $\mathrm{PhD}$ thesis, Faculty of Education. Mansoura University.

3) Al-Qadi, k.(2007). A suggested program for tacking difficulties facing university students English communication skills in Gaza, Unpublished M.A thesis, Faculty of Education University, Gaza

4) Ayed,M. (2011). The effect of using a suggested jigsaw based program on developing critical thinking, reading and reading motivation of first year English majors, M A thesis, faculty of education, Minia University.

5) Balci, S. (2006). Engagement, exploration, explanation, extension, and evaluation (5E) learning cycle and conceptual change text as learning tools. Biochemistry and Molecular Biology Education,

6) Boughy, C.(1997)."Learning to write by writing to learn: a group work approach." ELT J ournal.51 (2):126-135.34, 199-203.

7) Brown, D.(1994). Teaching by principles: An interactive approach to language.

8) Upper saddle River, NJ: prentice Hall.

9) Dole, J. (1991). Moving from the old to the new, research on reading comprehension. Review of educational research, 3 .

10) Ebedy, H. (2013): The effectiveness of a constructivism-based programme in developing some English reading and writing skills of prep school students and their attitudes. Unpublished doctoral thesis, Institute of educational studies, Cairo University

11) El-Deen, A.(2011). The effectiveness of a program based on social constructivist learning model in developing some metacognitive reading skills of the secondary first grades. Unpublished MA thesis, faculty of education, Ain shams University.

12) El-Deen, A.(2014).The effectiveness of an EFL program based on freirean pedagogy in developing secondary school students' argumentative writing skills and reflective thinking. Unpublished ph. D thesis, faculty of education, Ain Shams University

13) El-fiky, T. (2006). The effectiveness of a cooperative learning strategy in enhancing composition writing skills and attitudes of Al-Azhar secondary students. Unpublished M A thesis, faculty of education. Tanta University.

14) Eltorky, N. (2014). A suggested proposed program based on constructivism theory for developing business administration students' writing skills, Unpublished ph. D thesis, faculty of education, Ain shams university.

15) Helwa, H.(2014):The Effectiveness of a Program Based on the Combination of Relevance and Confidence Motivational Strategies in Developing EFL Argumentative Writing Skills and Overcoming Writing Apprehension Among Students Teachers at Faculty of Education. Faculty of Education, Benha University

16) Ismail, A. (2001). The effect of an integrated process-product approach to teaching writing on developing creative writing skills of first- year EFL majors at Sohag faculty of education. Unpublished $\mathrm{PhD}$ Dissertation, Sohag faculty of Education, South Valley University

17) Koc, G.(2002). Effects of constructivist learning approach on affective and cognitive learning 
outcomes. Hacettepe university, Ankara.

18) Lasheen, A. (2012) Effectiveness of a Courseware in the English Language Based on Narrative Technique to Develop some Critical

19) Reading Skills for Secondary School Students, Unpublished M. A thesis, faculty of Education, Ain Shams University.

20) Lee, O. \& Buxton, C. (2008). Science curriculum and student diversity: A framework for equitable learning opportunities. The Elementary School Journal, 109, 123-137.

21) Leeds, B.(1996).writing in a second learning. United States: Addison Wesley publishing company, Inc.

22) Magharious, G. \& Mc Cracken, K. (2009). Communities of effective practice, 2009-2009 evaluation. David Heil\& Associates, Inc. Unpublished Report

23) Mahmoud, M.(2007).the effect of using the constructivist learning model on the second cycle and basic education pupils' acquisition of some grammatical concept and their attitudes towards using the model. Unpublished M.A. Thesis in education, curriculum and instruction, faculty of education, Elfaum University.
24) Mansour, G.(2013) A suggested program for developing EFL reading and writing skills among secondary students in light of the constructivist learning approach. Unpublished $\mathrm{Ph}$. D thesis, faculty of education, Ain shams university.

25) Moore, S. (2009).The effects of being a reader and of observing readers on fifth grade students' argumentative writing. Unpublished doctoral dissertation, University of Delaware

26) Newton, J. (2009). Teaching ESL/ EFL Listening and Speaking, Routledge, New York.

27) Padesky, C.(1995)Clinicians guide to mind over mood New York: Guildford press

28) Rizk, S. (2008). The effectiveness of a constructivism-based program in developing the listening skills of EFL primary student teachers. Unpublished M.A. thesis. Faculty of Education, Mansoura University.

29) Wallace, C. (2003): Critical reading in language education: Great Britain Palgrave Macmillan.

30) Zaky, E.(2014).The effect of using electronic mapping on developing first year secondary stage students' EFL critical reading skills.

31) Unpublished MA thesis, faculty of education, Ain shams university 